\section{$\mathbb{T}$ Periodica Polytechnica Civil Engineering}

OnlineFirst (2018) paper 11080

https://doi.org/10.3311/PPci.11080

Creative Commons Attribution (i)

\title{
Response of Refractory Cement Based Composite to Gradual Temperature Loading
}

\author{
Ondřej Holčapek ${ }^{1}$, Jaroslava Kot'átková ${ }^{1}$, Petr Konvalinka ${ }^{1}$, and \\ Pavel Reiterman ${ }^{1 *}$
}

RESEARCH ARTICLE

Received 28 May 2017; Revised 05 September 2017; Accepted 23 January 2018

\begin{abstract}
This paper deals with the experimental study of the response of refractory concrete mixture to gradual thermal loading, up to $1000{ }^{\circ} \mathrm{C}$. A binding system based on calcium aluminate cement (CAC) modified by the partial replacement of metakaolin was used. Short ceramic fibers were applied in a dose of $4 \%$ by volume in the studied mixture. Material transformations due to thermal loading were monitored in terms of residual mechanical, fracture and basic physical properties-compressive strength, flexural strength, fracture energy, dynamic modulus of elasticity, and bulk density in the study. The results obtained corresponded well with the mineral transformations monitored using the thermogravimetric analysis performed on the binder paste. Residual values of compressive and flexural strength were approximately $40 \%$ of the initial values after exposure to a temperature of $1000^{\circ} \mathrm{C}$; however, the dominant part of the total loss was monitored up to $400^{\circ} \mathrm{C}$, due to decomposition of the hydrates. Fiber employment contributed considerably to the resistance against thermal loading up to $400^{\circ} \mathrm{C}$, which was demonstrated by the fracture energy results (a loss of $25 \%$ was monitored). An additional increase of the temperature load led to micro crack propagation, which was obvious in the results of dynamic modulus of elasticity determination, in which the short fiber incorporation was noticeably limited.
\end{abstract}

\section{Keywords}

refractory composite, metakaolin, ceramic fibres, elevated temperatures

\section{Introduction}

By refractories are usually presented as high utility composite materials, originally developed for industrial, technological, safety, or other special purposes, when the elevated temperatures take place. According to the location of the application, they protect various types of constructions, technologies, or how they can be used, e.g. for manufacture of monolithic furnaces in industrial production [1]. Due to the application in the environment with extreme conditions, the refractories consist of high utility and high quality raw materials, which are often expensive and very energy-intensive. Refractory materials can be characterized according to type of bond that provides a solid link between fillers and micro-fillers. Three main types of bonds in refractory composites are hydraulic bonds (created by hydration of aluminous cement), chemical bonds (replacement of aluminous cement by hydrated and reactive aluminium oxide), and ceramic bonds (formed by sintering filler and binder after an initial exposure up to $1000{ }^{\circ} \mathrm{C}$ ) $[2,3]$. Ceramic refractories exhibit the best resistance to increased temperatures, meaning that their testing is very laborious and instrumentally difficult. That is why, numerical instruments were developed to predict temperature dependent material changes [4, 5].

We can also classify refractories based on the method of production (shaped or unshaped). High-temperature refractory concrete, classified by their cement content, can be divided into conventional castables (CC), low cement castables (LCC), and ultra-low cement castables (ULCC) [6]. CC usually contains contents of more than $20 \%$ of CAC (calcium aluminate cement), LCC 6-15\%, and ULCC of less than 6\% of CAC [7]. Several conventional castables can be characterized as self-flow [8] with similar workability parameters, as is to be expected for self-compacting concrete.

The interaction of building materials and an environment with elevated temperatures is usually connected with degradation, microstructure, chemical changes, a decrease of mechanical properties, and volume changes, etc. Every building material is characterized according to its fire safety (ability to resist fire), usually classified in standards [9]. Concrete, the most widespread building material in the world, has 
satisfactory fire-resistance properties (compared with steel), that provides sufficient time for safe evacuation (tens of minutes). High strength concrete achieves lower fire-resistance, due to the explosive spalling phenomenon [10]. The explosive spalling took place between $300^{\circ} \mathrm{C}$ and $400^{\circ} \mathrm{C}$, and it is caused by an increase of pressure in the pore structure of HPC (due to the volume expansion of water in pores). Composites based on Portland cement characterizes the gradual decomposition of $\mathrm{CSH}$; at $400^{\circ} \mathrm{C}$ the portlandite $\mathrm{Ca}(\mathrm{OH})_{2}$ is decomposed to quick-lime and $\mathrm{CO}_{2}$. This process is accompanied by a decrease of mechanical properties, macroscopic cracks, and disintegration composite's structure.

The experimental program, presented in this article, is based on previous research, focused on the experimental investigation of an optimal composition of a refractory calcium aluminate cement-based composite with an addition of metakaolin, what means refractory composite with hydraulic bond. Several ratios between metakaolin and calcium aluminous cement were analysed. On the basis of values of fracture and mechanical characteristics, and also workability, the optimal modification of the basic mixture formula consisted of $4 \%$ volume fraction of ceramic fibres and $20 \%$ (of aluminous cement weight) of metakaolin. The process of the optimal composite composition development was published in [11]. Natural basalt aggregate was used in the described composite; therefore, the maximum temperature level was set at $1000^{\circ} \mathrm{C}$.

The main goal of this study was to describe the gradual changes of refractory cement composite previously developed for high temperature applications. Several changes are connected with the evaporation of free and physically bounded water, gradual decomposition of hydration products, and the mineral transformation of used aggregate. These changes influenced the basic and mechanical properties; therefore, all parameters (bulk density, flexural strength, compressive strength, dynamic modulus of elasticity, and fracture energy) were investigated after the specimen's exposure to various temperature loading levels $\left(105^{\circ} \mathrm{C}, 200^{\circ}, 300^{\circ} \mathrm{C}, \ldots, 900^{\circ} \mathrm{C}\right.$ and $1000^{\circ} \mathrm{C}$ ) for 180 minutes).

\section{Materials}

\subsection{Composite composition}

The aim of this research was to determine and quantify gradual changes of basic and mechanical properties of refractory cement composite reinforced by ceramic (alumina-silicate) fibers due to temperatures loading from $100^{\circ} \mathrm{C}$ to $1000^{\circ} \mathrm{C}$ (in $100^{\circ} \mathrm{C}$ gradient). The composition of the studied composite (see Table 1) was based on previous research, in which the optimized mixture was researched. The total amount of fibers, aluminous cement, and metakaolin determined the optimal solution, which was $180 \mathrm{~kg} / \mathrm{m}^{3}$ of metakaolin, $720 \mathrm{~kg} / \mathrm{m}^{3}$ of aluminous cement, and $4 \%$ of volume of fibers. Superplasticizer Sika SVC1035 ensured a low water-binder ratio $(0.25)$ and self-flow properties. The influence of elevated temperature on poly-carboxylate superplasticizer SVC had been investigated in [12], and with no negative implication detected. In this research, the various amounts of SVC were applied on the composite, and the mechanical properties were measured before and after exposure to $600^{\circ} \mathrm{C}$ and $1000^{\circ} \mathrm{C}$. The mixing procedure took place in a horizontal laboratory mixing machine; the first 5-minute phase consisted of homogenization of aggregates and fine components (cement and metakaolin), $50 \%$ of water was added in the second phase ( 1 minute), the remainder of the water with the plasticizer was added in the third phase ( 2 minutes), and the last phase consisted of adding the full dosage of fibers and their homogenization in composite ( 2 minutes). This fresh mixture was embedded into the steel moulds, and specimens $40 \times 40 \times 160 \mathrm{~mm}$ were manufactured.

\subsection{Basalt aggregate}

According to the maximum temperature of application, the optimal type of aggregate, or filler, was chosen. For a technical application to $700^{\circ} \mathrm{C}$, the natural aggregate is suitable, but only from selected types of rock (basalt, andesite, and diabase) [13]. For example, silica aggregates are unacceptable, due to volume expansion (approximately $0.5 \%$ ) at $573^{\circ} \mathrm{C}$, when $\alpha$-silica is change to $\beta$-silica [14]. Granite has the opposite problem, shrinkage of volume due elevated temperatures. Alternativelly could be used artificial aggregates for application up to $700^{\circ} \mathrm{C}$ (usually chamotte fireclay, bauxite, chromite, corundum, carborundum, slag, and electro-porcelain) [15]. The main filler of investigated cement composite was a combination of two fractions $(0 / 4 \mathrm{~mm}$ and $2 / 5 \mathrm{~mm})$ of natural crushed basalt aggregated, also used in [13]. High utility properties of natural basalt could be used for specific severe applications [16].

\subsection{High alumina cement}

The well-known, and thoroughly described, phenomenon of conversion [17] eliminates the application of aluminous cement only for the special purposes of refractory composites, but not for load-bearing structures. The properties of conventional castables (CC) based on hydraulic bond are mostly dependent on the qualities and purity of the aluminous cement that was utilized. Aluminous cements are classified according to the total amount of $\mathrm{Al}_{2} \mathrm{O}_{3}$, and various studies

Table 1 Composition of used refractory composite

\begin{tabular}{|c|c|c|c|c|c|c|}
\hline \multirow{2}{*}{$\frac{\text { Ceramic fibers }\left[\mathrm{kg} / \mathrm{m}^{3}\right]}{4 \% \text { by volume }}$} & \multicolumn{2}{|c|}{ Basalt aggregate $\left[\mathrm{kg} / \mathrm{m}^{3}\right]$} & \multicolumn{2}{|c|}{ Fine components $\left[\mathrm{kg} / \mathrm{m}^{3}\right]$} & \multicolumn{2}{|c|}{ Liquid components $\left[\mathrm{kg} / \mathrm{m}^{3}\right]$} \\
\hline & $0 / 4 \mathrm{~mm}$ & $2 / 5 \mathrm{~mm}$ & Cement Secar®71 & Metakaolin MefistoL05 & Plasticizer Sika SVC 1035 & Potable water \\
\hline 80 & 880 & 220 & 720 & 180 & 22.75 & 224 \\
\hline
\end{tabular}


have described the dependence of $\mathrm{Al}_{2} \mathrm{O}_{3}$ and suitable temperature ranges for their application [18]. The aluminous cement Secar71 used contained approximately $71 \%$ of $\mathrm{Al}_{2} \mathrm{O}_{3}$; therefore, it was suitable for utilization as a binder up to $1600^{\circ} \mathrm{C}$. Table 2 shows the detailed chemical composition of used cement. The specific surface of the cement utilized, measured by a Blaine apparatus, achieved $381 \mathrm{~m}^{2} / \mathrm{kg}$. Refractory cement composites achieved the lowest strength in the range $800^{\circ} \mathrm{C}$ $-900^{\circ} \mathrm{C}$; while the $\mathrm{CAH}$ was finally decomposed, although a ceramic bond was still not formed [19].

\subsection{Metakaolin}

Active pozzolanic materials (zeolite, metakaolin, ceramic powder, etc.) have a significant role in concrete and composite technology; this phenomenon has been confirmed by various studies focused on various topics $[20,21]$. We can find several successful applications of metakaolin in the field of refractory cement composites [22]. An amount of $180 \mathrm{~kg} / \mathrm{m}^{3}$ of metakaolin MefistoL05 from České lupkové závody, a.s., Czech Republic, with a specific surface of $306 \mathrm{~m}^{2} / \mathrm{kg}$ was used for the purpose of this experimental program. Metakaolin is produced by controlled calcining of raw clay, at approximately at $800^{\circ} \mathrm{C}$. The calcination temperature and quality of the input clay determine the metakaolin's properties.

\subsection{Fibers}

Granulated alumino-silicate fibers ISOWAT 12G, with a maximal application temperature $1260^{\circ} \mathrm{C}$ were used for reinforcement. These fibers contain a bulk density of $200 \mathrm{~kg} / \mathrm{m} 3$, with an average length ranging from 100 to $200 \mu \mathrm{m}$, and an average diameter of $10 \mu \mathrm{m}$. The surface treatment significantly influences behaviour during elevated temperature, because it provides the cohesion between fiber and the composite's matrix [23]. These types of fibers are used even for ordinary concrete, when $0.2 \%$ of volume improved the dynamic characteristics of ordinary reinforced concrete [24]. However, ceramic fibres could be successfully used also for ceramic refractories for severe applications [25].

Table 2 Chemical composition of fibers, cement, and metakaolin

\begin{tabular}{lccc}
\multicolumn{4}{c}{ (\% of weight) } \\
\hline Components & Secar & MefistoL05 & Fibers \\
\hline $\mathrm{Al}_{2} \mathrm{O}_{3}$ & 70.8 & 41.9 & 44.0 \\
$\mathrm{SiO}_{2}$ & 0.58 & 52.9 & 53.7 \\
$\mathrm{~K}_{2} \mathrm{O}$ & - & - & 0.20 \\
$\mathrm{CaO}$ & 27.5 & 0.13 & 0.22 \\
$\mathrm{TiO}_{2}$ & 0.37 & 1.8 & 0.60 \\
$\mathrm{Fe}_{2} \mathrm{O}_{3}$ & 0.42 & 1.08 & 0.66 \\
$\mathrm{SrO}_{2}$ & - & - & 0.01 \\
$\mathrm{ZrO}_{2}$ & - & - & 0.57 \\
$\mathrm{MgO}$ & 0.21 & 0.18 & - \\
\hline
\end{tabular}

\section{Used procedures}

\subsection{Thermal loading}

Manufactured specimens were preconditioned by the drying process up to $105^{\circ} \mathrm{C}$ to suppress explosive spalling during thermal loading. Sets of samples were subjected to thermal loading using an automatic electrical furnace at a heating rate of $10^{\circ} \mathrm{C} /$ min, with the exception of one control set for each studied mixture. The level of thermal loading was gradually increased by units of $100^{\circ} \mathrm{C}$ up to $1000^{\circ} \mathrm{C}$. The required thermal level was kept for an additional three hours, after which all samples were simultaneously cooled down to the room temperature. The process of thermal loading is illustrated on Fig. 1.

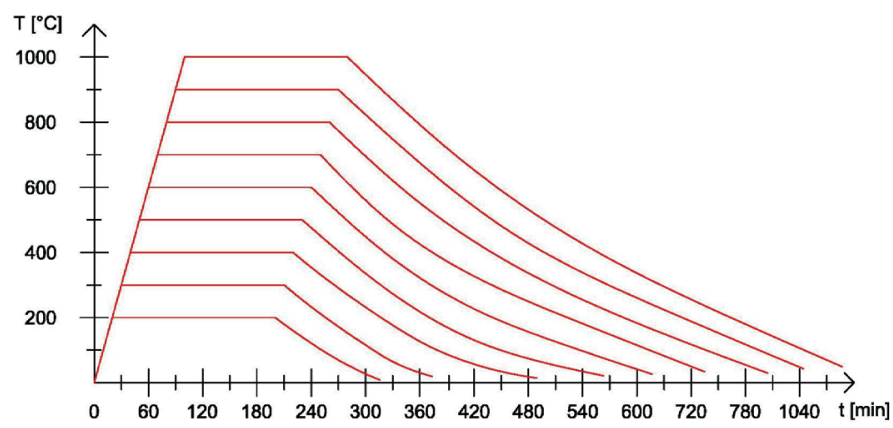

Fig. 1 Thermal loading cycles

\subsection{Investigated parameters}

Bulk density, flexural strength, compressive strength, and the dynamic modulus of elasticity were investigated on both the thermally loaded sets of samples and the control sets (dried to $105^{\circ} \mathrm{C}$ ). Mechanical testing was performed perpendicularly to the direction of compacting, which is a standard arrangement for cement-based composites. Each set consisted of three prismatic specimens.

Bulk density $\left(\rho_{\mathrm{m}}\right)$ was determined by the base of the actual weigh dimensions of the specimens. Mineralogical transformations are closely related to the values of the bulk density [26].

Flexural strength $\left(f_{t m}\right)$ determination was organized as a three-point bending test, with a support span of $100 \mathrm{~mm}$, according to [27], where $\mathrm{f}_{\mathrm{tm}}$ is calculated as a critical tensile stress of the rupture, using the theory of elasticity (1). A universal loading machine (MTS 100) and the operating system TestWorks 4 were used to control the test by the deformation rate of $0.2 \mathrm{~mm} / \mathrm{min}$. Deflection of the samples was recorded by the couple of extensometers.

Compressive strength $\left(\mathrm{f}_{\mathrm{cm}}\right)$ was determined using two fragments left after the flexural test. The loaded area of the samples was $40 \times 40 \mathrm{~mm}^{2}$. The value of $\mathrm{f}_{\mathrm{cm}}$ was calculated according to [27] (2).

$$
\begin{gathered}
f_{t m}=\frac{3 F_{t, \max }}{2 h b^{2}}, \\
f_{c m}=\frac{F_{c, \max }}{b h},
\end{gathered}
$$


$f_{c m}-$ compressive strength [MPa],

$F_{c, \max }$ - maximal reached force during compression test [N],

$b$ - width of the sample [mm],

$h$ - height of the sample [mm],

$f_{t m}-$ flexural strength [MPa],

$F_{t, \text { max }}$ - maximal reached force during flexural test [N].

The dynamic modulus $\left(\mathrm{E}_{\text {cum }}\right)$ of elasticity was measured using the ultrasonic pulse method, which presented the most frequently used non-destructive technique. The ultrasound speed $\left(\mathrm{v}_{\mathrm{L}}\right)$, by the coupling of $54 \mathrm{kHz}$ transducers and Pundit$\mathrm{Lab}+$ velocity test instruments produced by the Proceq company, was determined. The final values of the dynamic modulus of elasticity was then calculated according to (3).

$$
E_{\text {cum }}=v_{\mathrm{L}}^{2} \cdot \rho_{v} \cdot \frac{1}{k^{2}} \cdot 10^{-6}
$$

$E_{\text {cum }}$ - dynamic modulus of elasticity [GPa],

$v_{\mathrm{L}}-$ velocity of the impulse $[\mathrm{m} / \mathrm{s}]$,

$k$ - coefficient of sample sizing [-],

$\rho_{v}-$ bulk density $\left[\mathrm{kg} / \mathrm{m}^{3}\right]$.

From the recording of the flexural strength determination, the fracture energy Gfm $\left[\mathrm{J} \cdot \mathrm{m}^{-2}\right]$ was calculated. For the determination of fracture energy, the formula given in RILEM recommendation was used [28] (4).

$$
G_{f i n}=\frac{1}{b \cdot(h-n)} \int_{0}^{\delta_{\max }} F_{t, \max }(\delta) d \delta
$$

$G_{f m}$ - fracture energy $\left[\mathrm{J} / \mathrm{m}^{2}\right]$,

$F_{t, \text { max }}$ is force at failure in [N],

$\delta$ is deflection in $\mathrm{mm}$, a is width of the beam in [m],

$n$ is depth of the notch in [m].

\subsection{Thermogravimetric analysis}

Prismatic samples $40 \times 40 \times 160 \mathrm{~mm}$ were prepared for the thermogravimetric analysis by mixing used cement, with $25 \%$ replacement of metakaolin and a water/binder ratio 0.25 , which corresponds with the composite composition. Paste specimens were cured in similar condition as composite samples. They were dried at $105^{\circ} \mathrm{C}$, and homogenized in the laboratory mill after 28 days of aging. Thermogravimetric measurement was performed on approximately $50 \mathrm{mg}$ of the resulting powder by the monitoring of weight loss using temperature rate $10^{\circ} \mathrm{C} / \mathrm{min}$. The simultaneously applied DTA-TG apparatus (Schimadzu DTG-60H) used aerial condition in the measuring chamber. Three samples were measured for each studied material. Weight loss was monitored for specific temperature intervals matching the thermal loading levels.

\section{Results and discussion}

The gradual decline of bulk density value, due to the action of elevated temperatures and consequent transformations, can be observed from the chart in Fig. 2. The initial part of thermal loading is connected with the evaporation of both free and physically bounded water. The highest decline of bulk density took place in the temperature ranges of $300^{\circ} \mathrm{C}$ and $500^{\circ} \mathrm{C}$, which is in accordance with the decomposition of the hydration products, which resulted in a gradual decrease of bulk density. The final value of bulk density at $1000^{\circ} \mathrm{C}$ is $6.8 \%$, and less than at $100^{\circ} \mathrm{C}$.

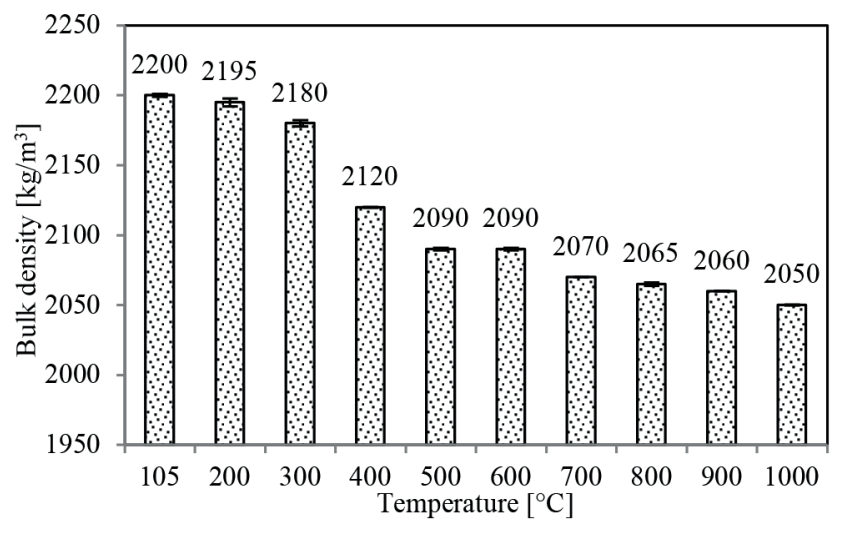

Fig. 2 Evaluation of bulk density

Compressive strength (Fig. 3) declined equally linearly due to the action of thermal loading with increasing temperature. The compressive strength of the specimen exposed to $300^{\circ} \mathrm{C}$ is at a $75.8 \%$ level of the reference value $\left(105^{\circ} \mathrm{C}\right), 600^{\circ} \mathrm{C}$ corresponds to $61.2 \%$, and $1000^{\circ} \mathrm{C}$ corresponds to $45 \%$ of the reference value.

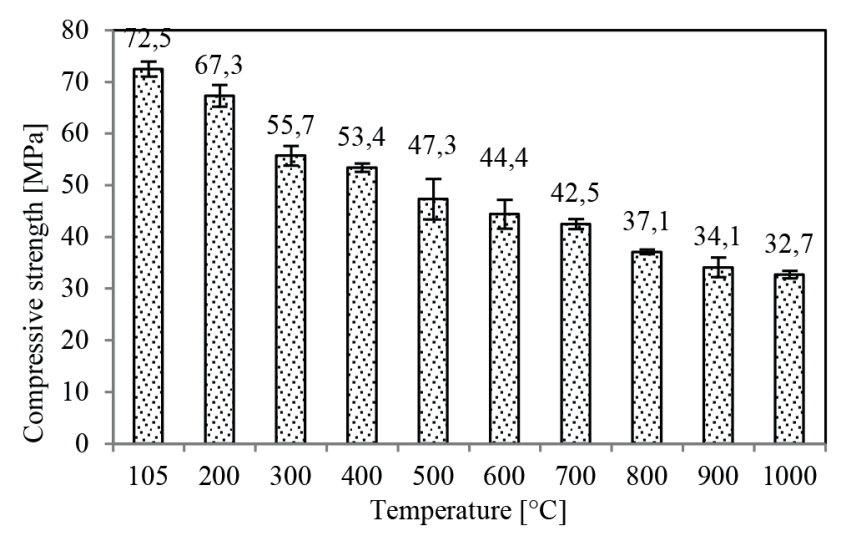

Fig. 3 Evaluation of compressive strength

A considerable decrease of flexural strength (Fig. 4) was monitored at $300^{\circ} \mathrm{C}(76.2 \%$ of origin value), after exposure to $400^{\circ} \mathrm{C}$ compressive strength declined to $55.4 \%$ of origin value, and the final compressive strength after exposure to $1000^{\circ} \mathrm{C}$ measured at the $41.5 \%$ level. The dynamic modulus of elasticity (Fig. 5) is also dependent on the bulk density; therefore, the trend follows bulk density values. The highest decline of fracture energy (Fig. 6) was realized between $200^{\circ} \mathrm{C}$ and $500^{\circ} \mathrm{C}$ (to $66.7 \%$ of original value). Further decline was successive without sudden changes. 


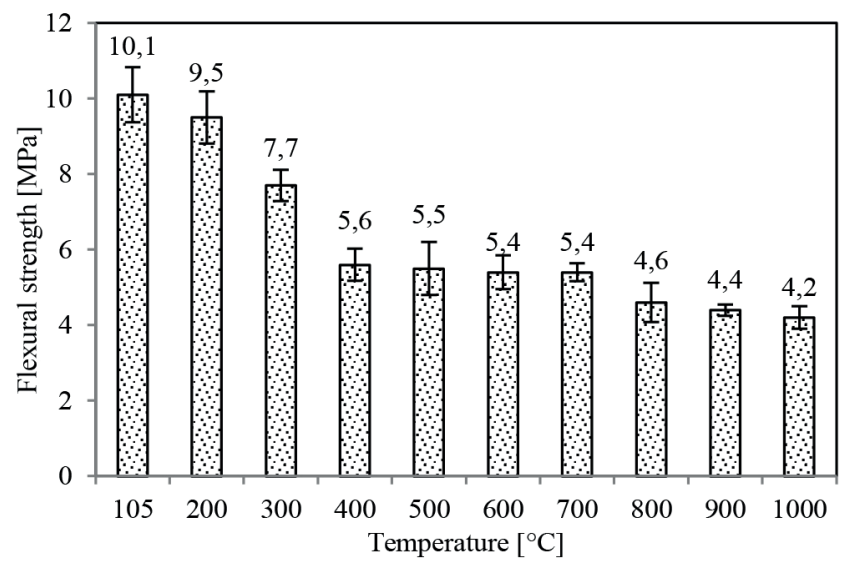

Fig. 4 Evaluation of flexural strength

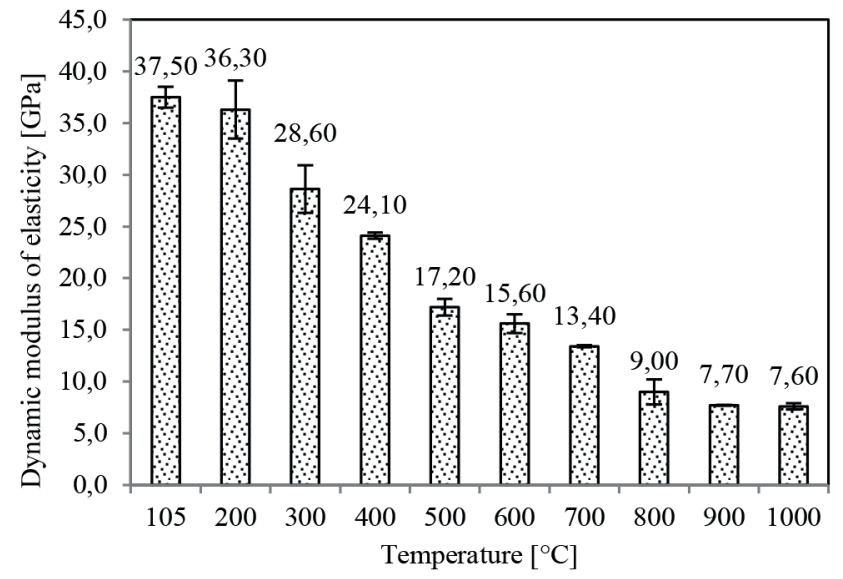

Fig. 5 Evaluation of dynamic modulus of elasticity

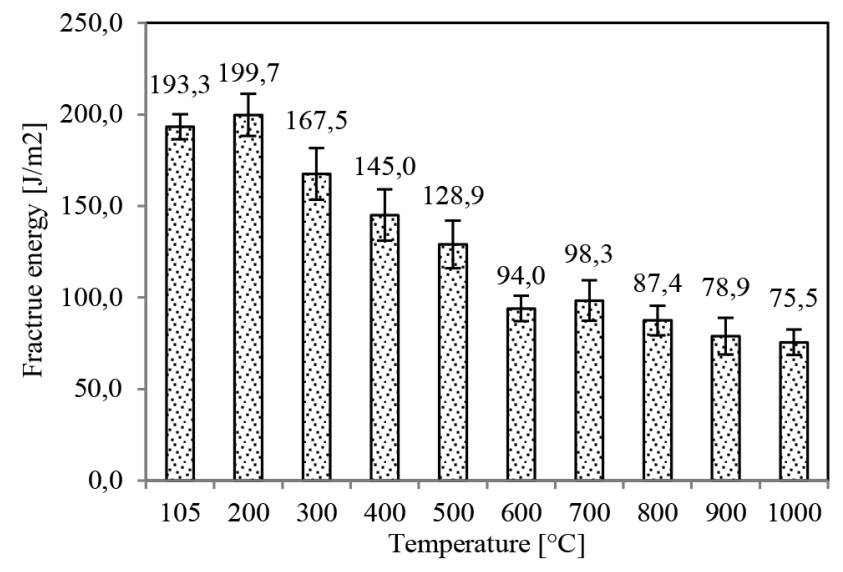

Fig. 6 Evaluation of fracture energy

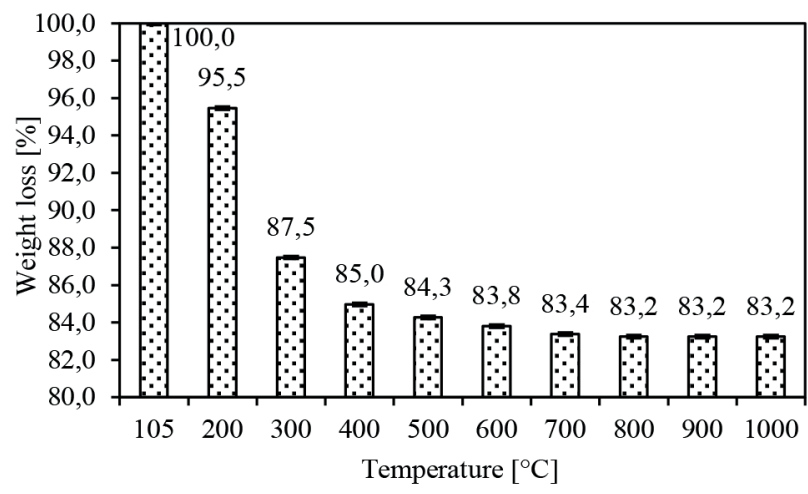

Fig. 7 Gradual weight loss determined using thermogravimetry
The resulting thermogravimetric measurement expressed by the cumulative weight loss of used binder corresponds well with the accompanied mineral changes. The dominant part of the decomposition of the formed hydrates took place up to $400^{\circ} \mathrm{C}$, Fig. 7, where the weight loss of about $15 \%$ was monitored. The resulting thermal loading did not affect the studied material to any considerable degree. Total weight loss obtained after $1000^{\circ} \mathrm{C}$ exposure was shown to be only $16.8 \%$.

\section{Conclusions}

The experimental work performed was focused on the detailed study of material transformations related to temperature loading. An investigation was carried out on the fiber composite mixture of optimized composition, which was developed in previous research. The studied composite was loaded by the elevated temperatures up to $1000^{\circ} \mathrm{C}$, by $100^{\circ} \mathrm{C}$ increments.

In terms of the investigated mechanical properties, it can be concluded that the residual values correspond well with the mineral changes, and with binder decomposition respectively, during the gradual temperature loading. The most common of the formed hydrates decomposed up to $400^{\circ} \mathrm{C}$, which was accompanied by the considerable decline of all the studied parameters that is specific to the calcium aluminate cementbased composites. The gradual increase of temperature load and consequent loss of mechanical properties was likely caused by the volume changes, accompanied by the initiation of cracks, resulting from the likely absence of siliceous component in the mixture, which decomposed after reaching a temperature of $573^{\circ} \mathrm{C}$. Gradual deterioration was evident in the results of NDT measurement; however, the studied composite kept its integrity without any visual damage. Nevertheless, the application of longer fibers would be beneficial, due to a higher contact zone with respect to the maximum size of the grain that was studied.

The absence of secondary rehydration processes is a significant advantage of composites based on the calcium aluminate cements, which allows reuse of the material, although with reduced mechanical properties. Composites based on traditional Portland cement exposed to elevated temperature often suffer from internal stresses arising from the secondary hydration of quick lime after contact with water.

The production of calcium aluminate cement is very energy intensive; nevertheless, this binding system is indispensable to composite production for application at high temperatures. The research focused on the CAC-based composite confirmed the possibilities for the increased energy efficiency of these composites using metakaolin replacement.

\section{Acknowledgement}

The authors gratefully acknowledge the support provided by the Czech Science Foundation under project P105/12/G059. 
The authors also gratefully acknowledge the assistance given by the technical staff of the Experimental Centre Department of the Faculty of Civil Engineering, CTU in Prague.

\section{References}

[1] Sadik, Ch., El Amrani, I.-E., Albizane, A. "Recentadvancesinsilica-aluminarefractory: A review”. Journal of Asian Ceramic Society, 2(2), pp. 83-96. 2006. 10.1016/j.jascer.2014.03.001

[2] Ebbrecht, T.,Weyershausen, B., Lipinski,T.R., Strohm,H. "A novel high performance binder for refractories". In: Proceedings of the Unified International Technical Conference on Refractories UNITECR 2007, pp. 388 390. 2007.

[3] Navrotsky, A. "Thermochemical insights into refractory ceramic materials based on oxides with large tetravalent cations". Journal of Materials Chemistry, 15, pp. 1883-1890. 2010. 10.1039/B417143H

[4] Longbiao, L. "Modeling matrix cracking of fiber-reinforced ceramic-matrix composites under oxidation environment at elevated temperature". Theoretical and Applied Fracture Mechanics, 87, pp. 110-119. 2017. 10.1016/j. tafmec.2016.11.003

[5] Deng, Y., Li, W.,Wang, R., Shao, J., Geng, P., Kou, H., Zhang, X., Ma, J. "Temperature dependent first matrix cracking stress model for the unidirectional fiber reinforced ceramic composites". Journal of the European Ceramic Society, 37, pp. 1305-1310. 2017. 10.1016/j.jeurceramsoc.2016.12.003

[6] Newman, J., Choo, B. S. “Advanced ConcreteTechnology 3: Processes.”, p. 704. 2003.

[7] Zivica, V., Palou, M. T., Bagel, L., Krizma, M. "Low-porosity tricalcium aluminate hardened paste". Construction and Building Engineering, 38, pp. 1191-1198. 2013. 10.1016/j.conbuildmat.2012.09.025

[8] Nandi, P.,Tiwari, L., Mukhopadhyay, M. S. "Micronized a-A12O3 in ZeroCement castables". American Ceramic Society Bulletin, 75(11), pp. 71-75. 1996.

[9] Czech Standards, CSN EN 13501-2 Fire classification of construction products and building elements - Part 2: Classification using test data from resistance firetests, excluding ventilation services (2003).

[10] Phan, L. T. "Pore pressure and explosive spalling in concrete". Materials and Structures, 41(10), pp. 1623-1632. 2008. 10.1617/s11527-008-9353-2

[11] Holcapek, O., Reiterman, P., Konvalinka, P., Kotatkova, J. "Fracture characteristics of refractory composites containing metakaolin and ceramic fibers". Advances in Mechanical Engineering, 7(3), p. 13. 2015. $10.1177 / 1687814015573619$

[12] Jogl, M., Reiterman, P., Holcapek, O., Kotatkova, J. "Influence of hightemperature on polycarboxylate superplasticizer in aluminous cement based fibre composites". Advanced Materials Research, 982, pp. 125-129. 2014. 10.4028/www.scientific.net/AMR.982.125

[13] Bodnárová, L., Hroudová, J.,Brožovský, J., Zach, J.,VálekJ. “Behaviour of cement composites with lightweight and heavyweight aggregates at high temperatures". Periodica Polytechnica Civil Engineering, 61(2), pp. 272 281. 2017. 10.3311/PPci.9365

[14] Stoch, L.,Laczka, M., Waclawska, I.’DTA and x-ray diffraction study of the phase transformation of silica minerals". Thermochimica Acta, 93, pp. 533-536. 1985. 10.1016/0040-6031(85)85134-0

[15] Jogl, M., Reiterman, P., Holčapek, O., Kot’átková, J., Konvalinka, P. "Residual properties of fiber-reinforced refractory composites with a fireclay filler". Acta Polytechnica, 56(1), pp. 27-32. 2016. 10.14311/ APP.2016.56.0027

[16] Zorla, E., Ipbüker, C., Biland, A., Kiisk, M., Kovaljov, S., Tkaczyk, A. H., Gulik, V. "Radiation shielding properties of high performance concrete reinforcedwith basalt fibers infused with natural and enriched boron". $\mathrm{Nu}$ clear engineering and Design, 313, pp. 306-318. 2017. 10.1016/j.nucengdes.2016.12.029
[17] Edmonds, R. N., Majumdar, A. J."The hydration of Secar 71 aluminous cement at different temperatures". Cement and Concrete Research, 19(2), pp. 289-294. 1989. 10.1016/0008-8846(89)90093-8

[18] Nonnet, E.,Lequeux, N., Bosh, P. "Elasticproperties of highalumina cement castables from room temperature to $1600^{\circ} \mathrm{C}$ ". Journal of the European Ceramic Society, 19(8), pp. 1575-1583. 1999. 10.1016/S09552219(98)00255-6

[19] Nilforoushan, M. R.,Talebian, N. "The hydration products of a refractory calcium aluminate cement at low temperatures". Iranian Journal Chemistry Chemical Engineering, 26(2), pp. 71-76. 2007. http://ijcce.ac.ir/article_7655_ca4433533bf77a35ad6e682ed5d20fd5.pdf

[20] Hossain, M. M., Karim, M. R.,Hassan, M.,Hossain, M. K., Zain,M. F. M. "Durability of mortar and concrete made up of pozzolansas a partialreplacement of cement: A review".Construction and Building Materials, 116, pp. 128-140. 2016. 10.1016/j.conbuildmat.2016.04.147

[21] Dinakar, P., Pradosh, K.,Sriram, G. "Effect of metakaolin content on the properties of high strength concrete". International Journal of ConcreteStructures and Materials, 7(3) pp. 215-223. 2013. 10.1007/s40069-0130045-0

[22] Enein, S.A.A.E.,Abou-Sekkina, M. M., Khalil,N. M., Shalma, O. A. "Microstructure and refractory properties of spinel containing castables". Ceramics International, 36(5), pp. 1711-1717. 2010. 10.1016/j.ceramint.2010.02.015

[23] Chen, Z.,Duncan, S., Chawla, K., Koopman, M., Janowski, G. "Characterization of interfacial reaction products in alumina fiber/barium zirconate coating/aluminamatrix composite". Materials Characterization, 48(4), pp. 305-314.2002. 10.1016/S1044-5803(02)00279-6

[24] Yiping, M.,Beirong, Z., Muhua, T. "Properties of ceramic fiber reinforced cement composites". Cement and Concrete Research, 35(2), pp. 296-300. 2005. 10.1016/j.cemconres.2004.05.017

[25] Shao, J.,Li, W., Deng, Y., Ma, J., Zhang, X., Geng, P., kou, H.,Chen, L., $\mathrm{Wu}, \mathrm{X}$. "Theoretical models and influencing factor analysis for the temperature-dependent tensile strength of ceramic fibers and their unidirectional composites". Composite Structures, 164, pp. 23-31. 2017. 10.1016/j.compstruct.2016.12.054

[26] Keppert, M., Vejmelková, E.,Švarcová, S.,Bezdička, P., Černý, R. “Microstructural changes and residual properties of fiber reinforced cement composites exposed to elevated temperatures". Cement Wapno Beton, 17(2), pp. 77-89. 2012.

[27] Czech Standard CSN EN196-1Methods of testing cement - Part 1: Determination of strength, 2005.

[28] RILEM, Materials and Structures, 18, 106, 1985, pp. 287-290. 10.1007/ BF02472918 